\title{
The Influence of Policy Implementation of Integrated Activity Monitoring Information System (SIMKET) Apllication Through the Characteristic of Information On Organizational Performance in the Central Bureau of Statistic of South Sumatera.
}

\author{
Guntur Teguh Iman \\ Badan Pusat Statistik Kabupaten Muara Enim \\ Email: gunturteguh@bps.go.id
}

\begin{abstract}
The purpose of this study was to determined the influence of policy implementation of integrated activity monitoring information system (SIMKET) application through the characteristic of information on organizational performance in the central bureau of statistics of South Sumatera. The population was respondents with the criteria of civil servants in the central bureau of statistics of the South Sumatera Province. The sampling method used was proportionate stratified random sampling. The method used in analyzing data is Structural Equation Modeling (SEM). The result of the study found that the implementation of integrated activities monitoring information system (SIMKET) application had an effect on the characteristic of information, characteristic of information had an effect on the organizational performance and the implementation of integrated activities monitoring information system (SIMKET) application had an unsignificant effect on organizational performance.
\end{abstract}

Keywords: policy implementation, characteristic of information, performance, structural equation modelling (SEM)

\section{Introduction}

Policy implementation is a crucial stage in the public policy process. A policy program must be implemented in order to have the impact or goals that the organization wants to achieve, in line with the research of Cavalluzzo (2004). Performance measurement is carried out to increase employee attention as an effort to implement a new measurement system to support organizational goals.

Law No. 16 of 1997, claim that statistics is important for planning, implementing, monitoring and evaluating the implementation of various activities in all aspects of social, national and state life in national development as the practice of Pancasila to advance the welfare of the people in order to achieve their goals. Nation is as stated in the Preamble to the 1945 Constitution.

According to Kilis's research (2015) standard operating procedures as a performance appraisal tool are oriented towards internal institutional performance, especially regarding the creation of operational fluency and the realization of coordination and monitoring of activities.

Adnan Hakim (2016) suggests that the quality of information has a positive and significant influence in improving manager performance, this shows that the available information must be accurate, timely, relevant, and a small error rate so that it can be used as good supervision and improve organizational performance.

In measuring the achievement of performance indicators, especially those related to statistical activities, Central Bureau of Statistic of South Sumatra Province issued a Decree of Central 
Bureau of Statistic of South Sumatra Province Number 001 / KPG Year 2018, which stipulates the Data Quality Control Team with the Integrated Activity Monitoring Information System (SIMKET) online application, SIMKET is a management information system innovation owned by the Provincial BPS and was implemented for the first time at the South Sumatera Provincial BPS in 2015 which is supported by the latest information technology to build networks. SIMKET aims to manage measurement, reporting, monitoring and evaluation activities. With the implementation of the SIMKET application, it can provide useful information as part of an organizational control system that is useful for controlling and monitoring activity processes and encouraging discipline in the percentage of document entry (response rate) as one of the main ingredients in measuring the achievement of BPS performance indicators for South Sumatera Province.

Because of the importance of the SIMKET application as one of the organization's internal performance assessments, it is necessary to have good information characteristics to encourage employees to try harder in achieving organizational goals. The impact on routine work monitoring with the SIMKET application can be implemented optimally so that the realization of the response rate is achieved according to the target of the organization.

The results of monitoring statistical activities in five technical fields, the percentage of document entry (response rate) surveys are in the good category, while other surveys that are below $80 \%$ are still categorized as feasible (Fowler Jr. et al, 2014) is a survey in the distribution statistics sector in the consumer price statistics section and HPB, and the production statistics section is the agricultural statistics section, the mining and energy statistics section, and the Industry statistics section.

From these facts it can be indicated that the implementation of the SIMKET application is still not optimal, even though the SIMKET program is one of the accesses to obtain information on the survey rate response which is one of the information on the performance indicators of BPS for South Sumatra Province.

Based on the background description, the researcher tries to conducting research with the title the Influence of the Policy Implementation of Integrated Activities Monitoring Information System (SIMKET) Application Through the Characteristic of Information on Organizational Performance in the Central Bureau of Statistics of the South Sumatera.

\section{Literature Review}

\subsection{Performance}

According to Fahmi (2014) The organization can be called a multi-role organization established with the aim of being able to provide and realize the wishes of various parties, and the owner's satisfaction is no exception. Furthermore, Stephen P. Robbins in (Fahmi, 2013) defines an organization as a consciously coordinated social entity, with a relatively identifiable boundary, which works on a relatively continuous basis to achieve a common goal or a group of goals.

(Spekle: 2013) Organizational performance is a work achievement achieved by work units in realizing predetermined targets, with performance indicators for public organizations. Meanwhile, organizational performance related to information systems according to Mithas (2011) is influenced by decision making, business processes from the information generated and the decision-making process. In this study, the performance of program/activity implementation, namely a description of the level of activity achievement by the Central Statistics Agency of South Sumatra Province in realizing its relevant objectives for the 
community. The dimensions of the organizational performance of this study are the achievement of targets, the level of accuracy, and the impact of the activities.

Ven and Ferry (in research journal Roland F Spekle and Frank H.M Verbeeten, 2013) performance is the work unit's achievement in realizing the targets that have been set, with performance indicators of public organizations; Indicators of activity performance achievement, level of program achievement, accuracy of work produced, realization of documents with achievements, impact of activity results, efficiency and employee behavior.

\subsection{Policy Implementation}

According to Al Fatih (2010) public policy is any decision or action made deliberately and legally by the government which aims to protect public interests, overcome public problems, empower the public and create public welfare. Types of public policies are divided into two groups, namely public policies that are normative in nature and public policies that are operational in nature. Public policy that is normative in nature serves as a formal juridical basis and to implement it requires further operational policies. Normative policies serve as a formal juridical foundation and to implement further policies that are operational in nature is required. Meanwhile, public policies that are operational are directly applicable without requiring further policies if they are to be implemented. Program (government) is a policy that is operational and can be directly implemented. Meanwhile, public policies that are operational are directly applicable without requiring further policies if they are to be implemented.

Meanwhile, Dye (in Tahir, 2015) states: "Public policy is what ever goverments choose to do or not to do", the concept of public policy is whatever the government chooses to do or not do

Purwanto and Sulistyastuti (2012) define the success of policy implementation as a description of the level of implementation achievement in realizing the goals and objectives of a policy, both in the form of policy outputs and policy outcomes.

According Edwards III (1980) states that the successful implementation of public policies that affect organizational performance is influenced by the following factors:

\section{Communication}

Communication is an important factor in implementing a policy. Implementers must know what the goals are to be achieved in implementing the policy. Provisions or rules for the implementation of policies must be conveyed to people precisely and clearly, accurately and consistently with regard to these provisions or rules. If this is not the case, there will be misunderstanding among them in implementing the policy, and the results are not as expected.

\section{Resources}

Resources have an important role in policy implementation, because even though the provisions or regulations conveyed are correct, policy implementers who are responsible for implementing policies are less professional and limited, such as staff, funds, authority and facilities to carry out work effectively, then the implementation of policies will not be effective. 


\section{Disposition}

Disposition in policy is defined as the tendency, desire or agreement of the implementers (the attitude of the executor) to implement the policy. In order for policy implementation to be effective and efficient, the implementers not only know what to do and the ability to implement the policy, but they must also have the will to implement the policy.

\section{Bureaucratic Structure}

The bureaucracy is one of the most frequent bodies that even implement policies as a whole. The bureaucracy plays an important role in implementing policies, because the bureaucracy is a government apparatus that has the task of translating and implementing every government policy.

\subsection{Information Characteristic}

According to Fahmi (2010) suggests the characteristics of information produced by a Management Information System (SIM) is a management tool that is used to support management in receiving, processing and managing the organization properly and systematically with the aim of supporting the creation of organizational performance.

For the survival and growth of many organizations today, the use of information technology or information systems is very important. Information systems provide new opportunities for redesigning business processes and work practices that allow changes to occur in organizations (Dedrick et al, 2003)

Furthermore, the theory used in this study as stated by Romney et. al. (2017) the information used must have five dimensions of quality or good information characteristics which are expected to improve overall performance:

1. Relevant, information is said to be relevant if the information can reduce uncertainty, be free from errors and bias, accurately describes the events or activities of the organization and increase the ability of decision makers to make predictions or confirm or correct their expectations in the past.

2. Reliable, information that is said to be reliable if the information is free from errors and bias, and accurately describes the events or activities of the organization.

3. Complete, information is said to be perfect or intact if it does not leave important aspects behind an event or activity to be measured

4. Timely, information is said to be timely if the information is available when decision makers use it to make decisions.

5. Understandable, namely information is said to be understood when the information is available and in a format that is useful, understandable and verifiable.

\section{Research Method}

This research design uses a quantitative approach. The quantitative approach format is used to see the effect between variables using and proving the hypothesis analyzed using inferential statistics. The research that the author will do is about the influence of implementing the SIMKET application through the characteristics of the information on the organizational performance of the Central Bureau of Statistics of South Sumatera. 
According to Al Fatih (2016) population is all data sources that have the right to become respondents or data sources. The population in this research plan is all civil servants in the BPS of South Sumatera Province, which are divided into six work units for the Statistics Section/field, (1) Administration, (2) Statistics Integration and Processing, (3) Social Statistics, (4) Production Statistics Sector, (5) Regional Balance Sheet and Statistical Analysis Sector, and (6) Distribution Statistics Sector, which is based on data from the Personnel Subdivision in August 2019, totaling 91 people. The number of samples in this study was determined based on the Slovin formula. Obtained a sample of 74 respondents.

From the description above, the SIMKET application implementation variable affects indirectly through the characteristics of information on the performance of the BPS of South Sumatera Province. This shows that the implementation of the SIMKET program has a direct effect on the variables of management information characteristics, then the variable characteristics of management information have a direct effect on the BPS performance variables and the implementation of the SIMKET program has a direct effect on the BPS performance variables. Based on this description, each variable is developed into the following indicators.

Variable (Y): Performace is the work unit's achievement in realizing the targets that have been set. The indicators are Performance Achievement, level of program achievement, accuracy of work produced, realization of documents with achievements, impact of activity results, efficiency and employee behavior.

Variable (Z): Information must have five dimensions of quality or good information characteristics which are expected to improve overall performance. The indicators are Relevant, Reliable, Complete, Timely, and Understandable.

Variable (X): Public policy implementation is a process of administrative activity that is carried out after the policy is approved. The indicators are Understanding communicant, Communication is conveyed, Relationship with communicator, Media used, Human resources, Number of computer, Internet, Commitment, Responsible, Ability, Work assignments, Standard operating Procedures, Integrated system, Predictions, Information in the past can be confirmed, error free, accurate, Complete information, Clear information, Information available when needed.

The research method that I use is a survey method with data collection techniques in the form of a questionnaire with a questionnaire instrument.

In quantitative research, the type of scale determines the formula and test statistics to be used. Because in this study the questionnaire statement was made using a Likert scale, so the type of measurement scale in this study is in the form of an ordinal scale. The ordinal scale according to Kadir (2015) if the numbers indicate rankings and do not show quantitative differences. The data obtained from distributing questionnaires using a Likert scale is an ordinal scale. According to Noor (2011) the measurement scale needed in arithmetic operations is an interval scale. Therefore, before testing the hypothesis using PLS-SEM, the data conversion from the ordinal scale to the interval is first performed. The stages of implementing the analysis include:
a) Validity Testing
b) Reliability Testing
c) Analysis Technique 


\subsection{Partial Least Square Equation Modeling (PLS-SEM)}

Ghozali (2008: 30) states that the purpose of PLS is to help researchers for predictive purposes. The formal model defines latent variables as linear aggregates of the indicators. The weight estimate for creating a latent variable score component is obtained based on how the inner model (measurement model, namely the relationship between the indicator and its construct) is specified. The result is the residual variance of the dependent variable.

PLS is an alternative approach that shifts from a covariance-based Structural Equation Model (SEM) approach to variant-based. Covariance-based SEM generally tests the quality of the theory, while PLS is more of a predictive model. PLS is a powerful analytical method. It does not have to meet the requirements of the data normality assumption and the sample size does not have to be large. Besides being able to be used as theoretical confirmation, PLS can also be used to build relationships where there is no theoretical basis or proposition testing. PLS provides leeway for the necessity of interval measurement and can be used on selected samples with a non-probability approach such as accidental sampling, purposive sampling and the like.

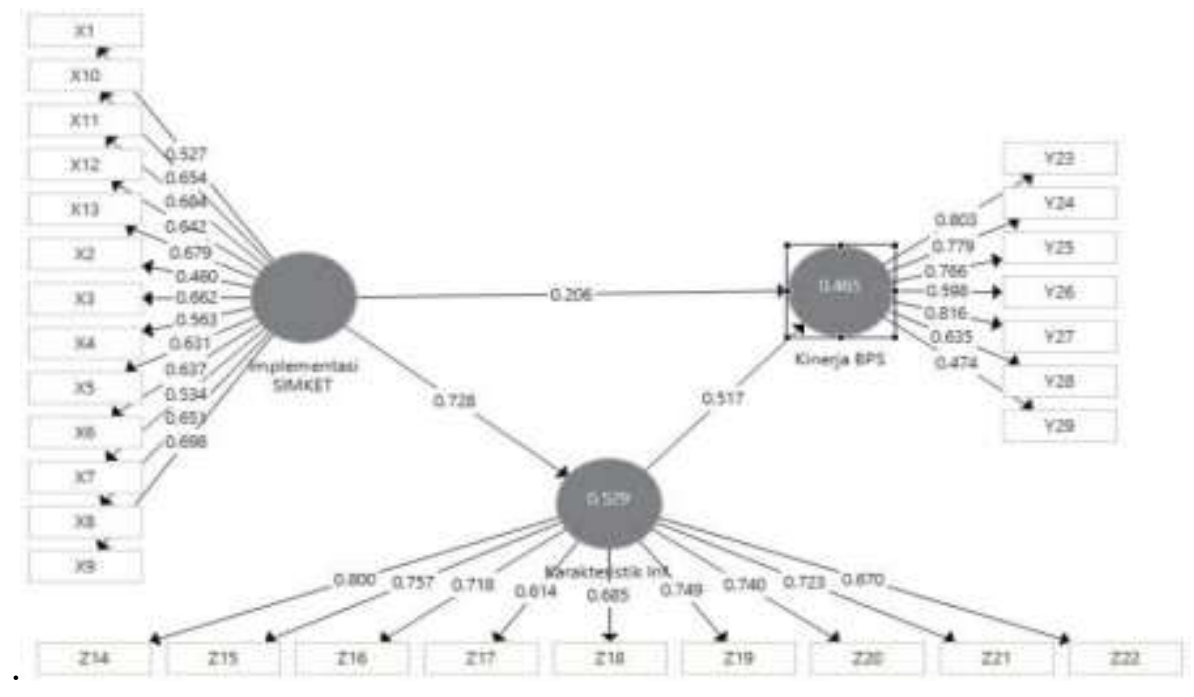

Figure 1. Full Model Diagram test results of construct validity of SIMKET Implementation, Information Characteristics and Performance of BPS South Sumatera Province

Source : Data processing

\subsection{Model Evaluation}

Model evaluation is done by looking at the significance to determine the effect between variables through the bootstrapping procedure. The bootstrap approach represents nonparametric precision to the PLS estimation. the bootstrap procedure uses the entire original sample for resampling. To test the effect between constructs or variables, the required significance value is a minimum t-value of 1.65 at the 10 percent significance level, a minimum t-value of 1.96 at the 5 percent significance level, and a minimum t-value of 2.58 at the 1 percent level of significance 


\section{Findings and Discussions}

The data analysis used was instrument test, PLS-SEM, hypothesis model and test, as follows:

\subsection{Partial Least Square Equation Modeling (PLS-SEM)}

Based on the result of calculations using the help of the SmartPLS 3.2.1 program, the result of the data validity test were obtained on the question items on the Information Characteristics (Z), Organizational Performance (Y), and Policy Implementation (X) variables. Valid at the level $(\alpha) 5 \%$ so that it can be used as a valid measuring tool in further analysis.

The test results show that the SIMKET implementation construct has a composite reliability value of 0.861 and Cronbach alpha of 0.806 . The value above is 0.7 as the cutoff value, so as many as six indicators regarding the implementation of SIMKET are reliable. The composite reliability and Cronbach alpha values of the information characteristic construct were 0.906 and 0.884 , respectively. This value indicates that the indicators of the information characteristic construct are reliable. The composite reliability and Cronbach alpha values of the BPS performance construct were 0.881 and 0.836 , respectively. This value indicates that the indicators of the BPS performance construct are reliable.

Furthermore, the construct diagram illustrates the relationship between SIMKET implementation variables, information characteristics and BPS performance. Furthermore, testing the inner model and outer model and testing the influence between variables.

After eliminating the low-value constructs and evaluating the convergent validity again, the loading factor for all constructs is obtained in Table 1

Table 1. Validity Test Results through convergent validity 2

\begin{tabular}{cccccc}
\hline Construct Indicators & $\begin{array}{c}\text { Original Sample } \\
\text { (Loading) }\end{array}$ & Standard Deviation & T stat. & P value & Inf. \\
\hline X5 & 0,713 & 0,055 & 13,051 & 0,000 & Valid \\
X8 & 0,686 & 0,072 & 9,555 & 0,000 & Valid \\
X9 & 0,745 & 0,053 & 13,991 & 0,000 & Valid \\
X11 & 0,740 & 0,057 & 13,037 & 0,000 & Valid \\
X12 & 0,717 & 0,059 & 12.086 & 0,000 & Valid \\
X13 & 0,671 & 0,077 & 8,702 & 0,000 & Valid \\
Z14 & 0,800 & 0,038 & 21,186 & 0,000 & Valid \\
Z15 & 0,759 & 0,038 & 19,836 & 0,000 & Valid \\
Z16 & 0,715 & 0,061 & 11,690 & 0,000 & Valid \\
Z17 & 0,619 & 0,098 & 6,313 & 0,000 & Valid \\
Z18 & 0,682 & 0,090 & 7,586 & 0,000 & Valid \\
Z19 & 0,743 & 0,063 & 11,810 & 0,000 & Valid \\
Z20 & 0,743 & 0,077 & 9,625 & 0,000 & Valid \\
Z21 & 0,728 & 0,090 & 8,095 & 0,000 & Valid \\
Z22 & 0,672 & 0,073 & 9,210 & 0,000 & Valid \\
Y23 & 0,810 & 0,054 & 14,905 & 0,000 & Valid \\
Y24 & 0,804 & 0,054 & 14,785 & 0,000 & Valid \\
Y25 & 0,751 & 0,054 & 13,971 & 0,000 & Valid \\
Y26 & 0,610 & 0,088 & 6,904 & 0,000 & Valid \\
Y27 & 0,825 & 0,043 & 19,006 & 0,000 & Valid \\
Y28 & 0,648 & 0,073 & 8,654 & 0,000 & Valid \\
\hline
\end{tabular}


On the testing stages of the measurement model through the validity and reliability test above, the items of the indicator statement from each construct have met the suggested validity and reliability values. Furthermore, this study will use 21 items of indicator statements from each construct that have been declared valid and reliable.

Table 2. Validity test results through discriminant validity 2 .

\begin{tabular}{ccccc}
\hline Construct & Indicator & $\begin{array}{c}\text { SIMKET } \\
\text { implementation }\end{array}$ & $\begin{array}{c}\text { Information } \\
\text { characteristics }\end{array}$ & $\begin{array}{c}\text { BPS } \\
\text { Performance }\end{array}$ \\
\hline \multirow{5}{*}{ SIMKET } & X5 & $\mathbf{0 , 7 1 3}$ & 0,531 & 0,350 \\
implementation & X8 & $\mathbf{0 , 6 8 6}$ & 0,504 & 0,316 \\
& X9 & $\mathbf{0 , 7 4 5}$ & 0,577 & 0,390 \\
& X11 & $\mathbf{0 , 7 4 0}$ & 0,506 & 0,340 \\
& X12 & $\mathbf{0 , 7 1 7}$ & 0,524 & 0,400 \\
& X13 & $\mathbf{0 , 6 7 1}$ & 0,493 & 0,367 \\
\hline \multirow{6}{*}{ Information } & Z14 & 0,580 & $\mathbf{0 , 8 0 0}$ & 0,432 \\
& Z15 & 0,752 & $\mathbf{0 , 7 5 9}$ & 0,519 \\
& Z16 & 0,517 & $\mathbf{0 , 7 1 5}$ & 0,536 \\
& Z17 & 0,407 & $\mathbf{0 , 6 1 9}$ & 0,396 \\
& Z18 & 0,359 & $\mathbf{0 , 6 8 2}$ & 0,449 \\
& Z19 & 0,626 & $\mathbf{0 , 7 4 3}$ & 0,531 \\
& Z20 & 0,443 & $\mathbf{0 , 7 4 3}$ & 0,478 \\
& Z21 & 0,523 & $\mathbf{0 , 7 2 8}$ & 0,326 \\
& Z22 & 0,413 & $\mathbf{0 , 6 7 2}$ & 0,472 \\
\hline \multirow{6}{*}{ BPS } & Y23 & 0,316 & 0,492 & $\mathbf{0 , 8 1 0}$ \\
& Y24 & 0,385 & 0,475 & $\mathbf{0 , 8 0 4}$ \\
& Y25 & 0,378 & 0,470 & $\mathbf{0 , 7 5 1}$ \\
& Y26 & 0,288 & 0,469 & $\mathbf{0 , 6 1 0}$ \\
& Y27 & 0,466 & 0,504 & $\mathbf{0 , 8 2 5}$ \\
& Y28 & 0,421 & 0,468 & $\mathbf{0 , 6 4 8}$ \\
\hline
\end{tabular}

Source : Data processing

The results of the Discriminant Validity test of the two crossloading indicators on the SIMKET implementation construct, information characteristics and performance of the BPS of South Sumatra Province are shown in Table 2. Discriminant Validity still shows good criteria because of crossloading indicators of the SIMKET implementation construct, information characteristics, and BPS performance. has more crossloading than other constructs.

Table 3. Validity test results through discriminant validity AVE 2

\begin{tabular}{lcc}
\hline \multicolumn{1}{c}{ Constructs } & AVE & Information \\
\hline SIMKET Implementation & 0,508 & Valid \\
Information Characteristic & 0,518 & Valid \\
BPS Performance & 0,557 & Valid \\
\hline
\end{tabular}

Source : Data processing 
Testing the outer model is carried out after removing several indicators so that the AVE value is above 0.5. The results of the second AVE output indicate that the AVE value for the SIMKET Implementation construct, Information Characteristics and Performance of BPS is declared valid because it already has an AVE of more than 0.5.

Table 4. Construction Reliability Test Results of SIMKET Implementation, Information Characteristics and BPS Performance

\begin{tabular}{ccccc}
\hline No & Constructs & $\begin{array}{c}\text { Composite } \\
\text { reliability }\end{array}$ & $\begin{array}{c}\text { Cronbachs } \\
\text { Alpha }\end{array}$ & Information \\
\hline 1 & $\begin{array}{c}\text { SIMKET } \\
\text { Implementation } \\
\text { Information }\end{array}$ & 0,861 & 0,806 & ReliabLe \\
Characteristic & 0,906 & 0,884 & ReliabLe \\
3 & $\begin{array}{c}\text { BPS } \\
\text { Performance }\end{array}$ & 0,881 & 0,836 & ReliabLe \\
\hline
\end{tabular}

Source : Data processing

The test results show that the SIMKET implementation construct has a composite reliability value of 0.861 and Cronbach alpha of 0.806 . The value above is 0.7 as the cutoff value, so as many as six indicators regarding the implementation of SIMKET are reliable. The composite reliability and Cronbach alpha values of the information characteristic construct were 0.906 and 0.884 , respectively. This value indicates that the indicators of the information characteristic construct are reliable. The composite reliability and Cronbach alpha values of the BPS performance construct were 0.881 and 0.836 , respectively. This value indicates that the indicators of the BPS performance construct are reliable.

Table 5. R-Square Value

\begin{tabular}{cc}
\hline Variable & $R$-Square \\
\hline Information Characteristic & 0,540 \\
BPS Performance & 0,419 \\
\hline
\end{tabular}

Source : Data processing

Table 5 shows that the R-square value of the information characteristic construct is 0.540 and the R-square value for the BPS performance construct is 0.419 . The R-square value for the information characteristic construct is 0.540 which means that 54 percent of the variance of information characteristics can be explained by the SIMKET implementation construct. While the BPS performance construct value is 0.419 which means that 41.9 percent can be explained by the SIMKET implementation construct and the information characteristic construct. The Rsquare value above 0.33 indicates that the influence model of SIMKET implementation through information characteristics on BPS performance is a moderate model (Ghozali and Latan, 2015: 81). In other words, the effect of exogenous latent variables on endogenous latent variables has a substantive effect. 


\subsection{Model Evaluation.}

Table 6. SmartPLS output regarding predictive relevance (Q2) for the construct of the SIMKET implementation variable, characteristics of information on the BPS performance.

\begin{tabular}{cccc}
\hline & SSQ & SSE & $\mathbf{Q}^{\mathbf{2}}(\mathbf{= 1 - S S E} / \mathbf{S S Q})$ \\
\hline $\begin{array}{c}\text { SIMKET } \\
\text { Implementation } \\
\text { Information } \\
\text { Characteristic } \\
\text { BPS Performance }\end{array}$ & 444.000 & 444.000 & \\
\hline
\end{tabular}

\section{Source : Data processing}

The evaluation of the PLS model can also be done by looking at the predictive relevance (Q2) value. The value of $\mathrm{Q} 2>0$ indicates that the model has predictive relevance, while the value of Q2 $<0$ indicates that the model lacks predictive relevance. The predictive relevance (Q2) values are presented in Table 5.16. Based on the table below, the results by data show that the $\mathrm{Q} 2$ values are 0.257 and 0.221 . The value of Q2>0 indicates that this model has predictive relevance.

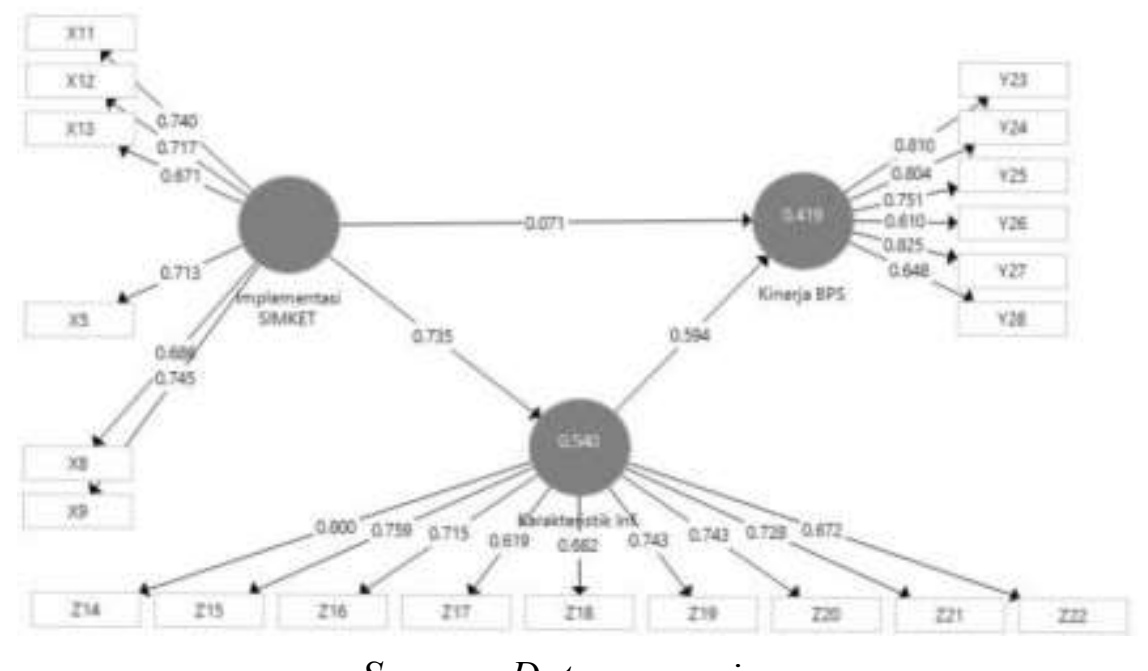

Source : Data processing

Figure 2. Full model diagram of the influence of the SIMKET implementation variables, information characteristics and BPS performance 
Table 6. Model Structural Test Results

\begin{tabular}{|c|c|c|c|c|c|}
\hline Hypothesis & Construcs & $\begin{array}{l}\text { Original } \\
\text { Sampel } \\
\text { Estimate }\end{array}$ & $\begin{array}{l}\text { Standard } \\
\text { Deviation }\end{array}$ & $\begin{array}{c}\mathrm{T}- \\
\text { Statistik }\end{array}$ & nformation \\
\hline $\mathrm{H}_{1}$ & $\begin{array}{l}\text { SIMKET Implementation } \\
\text { Information characteristics }\end{array}$ & 0,735 & 0,044 & 16,686 & Significant \\
\hline $\mathrm{H}_{2}$ & $\begin{array}{l}\text { Information characteristics } \rightarrow \\
\text { BPS Performance }\end{array}$ & 0,594 & 0,119 & 4,989 & Significant \\
\hline $\mathrm{H}_{3}$ & $\begin{array}{l}\text { SIMKET Implementation } \rightarrow \text { BPS } \\
\text { Performance }\end{array}$ & 0,071 & 0,150 & 0,474 & $\begin{array}{l}\text { Not } \\
\text { significant }\end{array}$ \\
\hline
\end{tabular}

Source : Data processing

The first hypothesis states that SIMKET implementation has a positive effect on Information Characteristics. The results of testing the hypothesis of the relationship between SIMKET Implementation and Information Characteristics at a significant level of $\alpha$ of 0.05 indicate a positive effect of 73.5 percent (based on the path coefficient value of 0.735 ) with a t-statistic value of 16.686 . The statistical value is far above the critical value of 1.96 , thus the first hypothesis can be accepted.

The second hypothesis states that information characteristics have a positive effect on BPS performance. The results of testing the hypothesis of the relationship between Information Characteristics and BPS Performance at a significant level of $\alpha$ of 0.05 indicate a positive effect of 59.4 percent (based on the path coefficient value of 0.594 ) with a t-statistic value of 4.989. The statistical value is above the critical value of 1.96 , thus the second hypothesis can be accepted.

The third hypothesis states that SIMKET implementation has a positive effect on BPS performance. The results of testing the hypothesis of the relationship between SIMKET Implementation and BPS Performance at a significant level of 0.05 indicate a positive influence of 7.1 percent (i.e. based on the path coefficient value of 0.071 ), but with a t-statistic value of 0.474 , the t-statistic value is is below the critical value range of 1.96 which means it is not significant. Thus the third hypothesis is rejected.

\subsection{Discussion.}

4.3.1 The Effect of SIMKET Implementation on Characteristic of the Information in the Central Bureau of Statistic of the South Sumatera

The results of the first hypothesis testing concluded that the SIMKET implementation had a positive effect on the characteristics of the information. The magnitude of the effect value of SIMKET implementation on information characteristics was $73.5 \%$. The results of this study support Dona Primasari's (2017) research, namely that the implementation of the Regional Financial Information System will help produce quality financial report information, this quality information becomes the basis for employees in making decisions, especially highlevel employees and can be used as a performance measurement tool. The results of this study also support the theory (Fahmi, 2010) that the characteristics of information which are the output of information systems are a tool for measuring organizational performance. 
Indicators of the number of human resources in the computer sector, having a commitment to a good organization, the responsibility of SIMKET operators, a clear division of entry tasks, the availability of standard operating procedures, the existence of an integrated system will increase the success of implementing the SIMKET application. The results of this study are in line with previous research, such as Julastri Rondonuwu, (2013) that policy implementation will be successful if it optimizes existing resources.

4.3.2 The Effect of Characteristic of the Information on BPS Performance in the Central Bureau of Statistic of the South Sumatera

The results of testing the second hypothesis concluded that the characteristics of the information had a positive effect on the performance of BPS. The magnitude of the value of the effect of information characteristics on BPS performance is $59.4 \%$. The results of this study prove that the results of the management of document entry generated from the SIMKET application create a document entry performance of the BPS of South Sumatra Province with a performance achievement of $98 \%$. The results of this study support the theory of Romney et al (2017) which states that information that has relevant dimensions, reliability, is complete, timely, and understandable is expected to improve overall performance. The results of this study also support the results of previous studies such as Waspodo (2014), Evelyne (2003) where they stated that the characteristics of information have a positive effect on organizational performance. This means that the better the characteristics of the information generated by the implementation of the SIMKET application, the performance of the BPS of South Sumatra Province will increase, conversely, if the characteristics of the information generated decrease, it can cause the performance of the BPS of South Sumatra Province to also decrease.

4.3.2 The Effect of SIMKET Implementation on BPS Performance in the Central Bureau of Statistic of the South Sumatera

The results of the third hypothesis concluded that the implementation of SIMKET has a positive but insignificant effect on organizational performance. The value of the influence of SIMKET implementation on organizational performance is $7.1 \%$ but not significant. The results of achieving document entry performance (response rate) using the SIMKET application in 2018 reached $98.28 \%$, the impact on the performance of the BPS of South Sumatra Province is indicated by other factors such as leadership. (Melchar, 2010) leaders who serve in the organization will produce positive performance and will be more committed to organizational values and can maintain high levels of performance.

\section{Conclusions}

Based on the results of research and testing of the hypotheses proposed in this study, the implementation of policies related to management information systems, in this case the output produced is characteristic of information, does not automatically have a direct effect on organizational performance. Policy implementation will be optimal if all dimensions can be implemented completely so that the resulting information output can be used by the leadership for planning, coordination and evaluation evaluation processes which will later become guidelines in the future and become a benchmark in organizational performance. Thus, the implementation of the Integrated Activity Monitoring Information System (SIMKET) application policy will help produce quality response rate information characteristics, this response rate report information becomes the basis for employees in making decisions, especially top level leaders, and can be used as a performance measurement 
tool. organization.

In this study, based on the path coefficient and statistical significance $t$, the direct effect of the SIMKET implementation on BPS performance is insignificant, so it can be stated that the mediation type is full mediation. It is declared full mediation, based on the fact that the results of the analysis do not find any other route from the implementation of the SIMKET application policy, except only through the information characteristic path.

The theoretical implications that can be proposed and constitute a novelty of this research case study are as follows; SIMKET implementation will be optimal if the existing information technology can be used by the head of the South Sumatra Provincial BPS for planning, coordination and evaluation evaluation processes which will later be used as guidelines in the future and become a benchmark in document management performance. Because by increasing the management of information systems it can create better opportunities in creating organizational performance

\section{References}

Al-Fatih, A. 2010. Implementasi Kebijakan dan Pemberdayaan Masyarakat. Bandung: UNPAD PRESS.

\section{Al-Fatih, A. 2016. Dasar-dasar Metodologi Penelitian Sosial. Palembang: Unsri Press.}

Cavalluzzo, K. I. (2004). Implementing performance measurement innovations: evidence from goverment. Accounting, Organizations and Society, 243-267.

Dedrick, J. Gurbaxani, V., \& Kraemer, K. L. (2003). Information Technology and Economic Performance: A Critical Review of the Empirical Evidence. ACM Computing Surveys (CUSR), 35(1). 1-28

Edwards III, George C. 1980. Implementing Public Policy. United States of America: Congressional Quaterly Inc.

Evelyne, J. D. (2003). Hubungan karakteristik Informasi Yang Dihasilkan Oleh Sistem Informasi Akuntansi Manajemen Terhadap Kinerja Manajerial Pada Perusahaan-Perusahaan Manufaktur di Jawa timur. Jurnal Akuntansi, 110-122.

Fahmi, Irham. 2010. Manajemen Kinerja Teori dan Aplikasi. Bandung: CV. Alfabeta.

Fahmi, Irham. 2013. Perilaku Organisasi. Bandung: Alfabeta, CV

Fowler Jr, Floyd J. 2014. Survey Research Methods. Boston: SAGE Publications.

Ghozali, I. 2015. Partial Least Squares Konsep, Teknik dan Aplikasi Menggunakan Program SMARTPLS 3.0 Untuk Penelitian Empiris. Semarang: Badan Penerbit Universitas Diponegoro Semarang.

Hakim, A. (2016). Model Struktural Hubungan Teknologi Informasi, Kualitas Informasi dan Kinerja Manajerial Industri Kreatif Percetakan Digital. Jurnal MIX, 83-102.

Julastri Rondonuwu, L. T. (2013). Manajemen Perubahan di Lembaga Pemerintah: Studi Kasus Implementasi Kebijakan Pelaksanaan PPK-BLUD di Rumah Sakit Jiwa Provinsi NTB. Jurnal Kebijakan Kesehatan Indonesia, 163-170.

Kadir. 2015. Statistika Terapan Konsep, Contoh, dan Analisa Data dengan Program SPSS/Lisrel dalam Penelitian Edisi Kedua.. Jakarta: PT. Rajagrafindo Persada. 
Kilis, A. P. (2015). Penerapan Standar Operasional Prosedur Dalam Pelaksanaan Tugas Pemerintah Kecamatan malalayang Kota Manado. Jurnal Politico, 116-127.

Melchar, D. E. (2010). Achieving High Organization Performance through Servant Leadership. The Journal of Business Inquiry, 74-88.

Mithas, S., \& Rust, R. T. (2016). How information Technology Strategy and Investment Influence Firm Performance: MIS Quarterly, 35(1), 237-256.

Noor J. 2011. Metode Penelitian. Jakarta: Kencana Prenadamedia Group.

Primasari, D. (2017). Pengaruh Implementasi Sistem Informasi Keuangan Daerah dan Kinerja Pegawai. Jurnal Ilmu Akuntansi, 153-166.

Purwanto, Erwan Agus dan Dyah Ratih Sulistyatuti. 2012. Implementasi Kebijakan Publik Konsep dan Aplikasinya di Indonesia. Yogyakarta: Gava Media.

Roland F. Spekle, F. H. (2013). The use of performance measurement systems in the publicsector: Effects on performance. Management Accounting Research.

Romney et al. 2017. Accounting Information System. United States: Pearson Education Inc.

Tahir, Arifin. 2015. Kebijakan Publik \& Transparansi Penyelenggaraan Pemerintah Daerah. Bandung: Alfabeta.

Waspodo, L. (2014). Pengaruh Implementasi Software Akuntansi Terhadap Kinerja Pegawai: Perceived Enjoyment dan Computer Playfulness Sebagai Variabel Moderating. Jurnal Manajemen Bisnis.

\section{Copyrights}

Copyright for this article is retained by the author(s), with first publication rights granted to the journal.

This is an open-access article distributed under the terms and conditions of the Creative Commons Attribution license (http://creativecommons.org/licenses/by/4.0/) 